\title{
Burial of terrestrial organic matter in marine sediments: A re-assessment
}

\author{
David J. Burdige \\ Department of Ocean, Earth and Atmospheric Sciences, Old Dominion University, Norfolk, Virginia, USA \\ Received 3 September 2004; revised 8 August 2005; accepted 29 August 2005; published 29 October 2005.
}

[1] Calculations based on recent observations indicate that approximately one third of the organic matter presently being buried in marine sediments may be of terrestrial origin, with the majority of this terrestrial organic matter (TOM) burial occurring in muddy, deltaic sediments. These calculations further suggest that the remineralization of terrestrial organic matter in the oceans is also much less efficient than that of marine organic matter. These two underappreciated observations have important implications in terms of our understanding of the controls on the global carbon cycle. From a paleoceanographic perspective, the results presented here also suggest that changes in TOM burial on glacial-interglacial timescales have the potential to impact the global carbon cycle (i.e., atmospheric $\mathrm{CO}_{2}$ levels).

Citation: Burdige, D. J. (2005), Burial of terrestrial organic matter in marine sediments: A re-assessment, Global Biogeochem. Cycles, 19, GB4011, doi:10.1029/2004GB002368.

\section{Introduction}

[2] Understanding the fate of terrestrial organic matter (TOM) in marine sediments is of importance for a number of reasons. In part, this interest stems from the observation that marine organic matter is broadly considered to be more reactive than terrestrial organic matter [Aller et al., 1996; Aller and Blair, 2004; Burdige, 1991; Cowie et al., 1992; Prahl et al., 1997]. Therefore one might suppose that marine organic matter deposited in sediments should be preferentially remineralized, and thus subject to less efficient burial. Similarly, terrestrial organic matter deposited in marine sediments might then be expected to undergo less efficient remineralization and therefore be preferentially buried. However, an examination of the carbon budget for the oceans suggests that roughly two to three as much organic carbon is transported to the oceans from land by rivers than is buried in marine sediments [Berner, 1989; Hedges and Keil, 1995]. Therefore, depending on the amount of TOM that does escape remineralization in the oceans to be buried in marine sediments, the burial efficiency of TOM in marine sediments must (at a minimum) be less than 50\%. (Burial efficiency, or $\mathrm{BE}$ is defined here as the organic matter burial rate at depth in sediments, i.e., below the surface zone of active remineralization, divided by the organic matter input rate. Oftentimes this organic matter input term is taken to be deposition at the sediment surface, i.e., the rain rate to the sediments. However in the discussions here, TOM burial efficiency is generally calculated with respect to riverine input of TOM to the oceans. Burial

Copyright 2005 by the American Geophysical Union. 0886-6236/05/2004GB002368\$12.00 efficiencies calculated in this fashion therefore incorporate both water column and sediment processes. Another term often used in such discussions is remineralization efficiency, or RE; this is the ratio of the rate of sediment organic carbon remineralization to the rate of organic carbon input. On the basis of this formulation, $\mathrm{BE}=1-$ RE.)

[3] In fact, as will be discussed below, TOM burial efficiency is indeed relatively low, or conversely, its remineralization efficiency is relatively high (also see discussions by Hedges et al. [1997]). This then appears to imply that the oceans are fairly efficient at the remineralization of refractory terrestrial organic matter in the oceans, yet bury, or preserve, marine organic matter that is presumably more reactive. As Hedges et al. [1997] note, the resolution of this geochemical "conundrum" has important implications in terms of understanding oceanic carbon cycling and the controls on sediment carbon burial and preservation.

[4] At the same time, only a small fraction ( $20 \%$ or less $)$ of riverine suspended matter is deposited in deep-sea sediments [Berner and Berner, 1996; McKee et al., 2004]. As a result, much of the particulate TOM transported by rivers to the oceans is deposited in continental margin sediments. Since continental margin sediments are also the major sites of sediment carbon burial and remineralization [Berner, 1989; Hedges and Keil, 1995], this further suggests that there should be a linkage between TOM burial and remineralization in sediments and sediment carbon preservation in general.

[5] Finally, the fate of TOM in marine sediments is of importance since it is generally assumed that most terrestrial, riverine dissolved organic matter (DOM) is remineralized in the marine water column [Hedges, 1992]. Thus TOM burial in sediments, like burial of organic matter (in general), represent an important link between "active" 

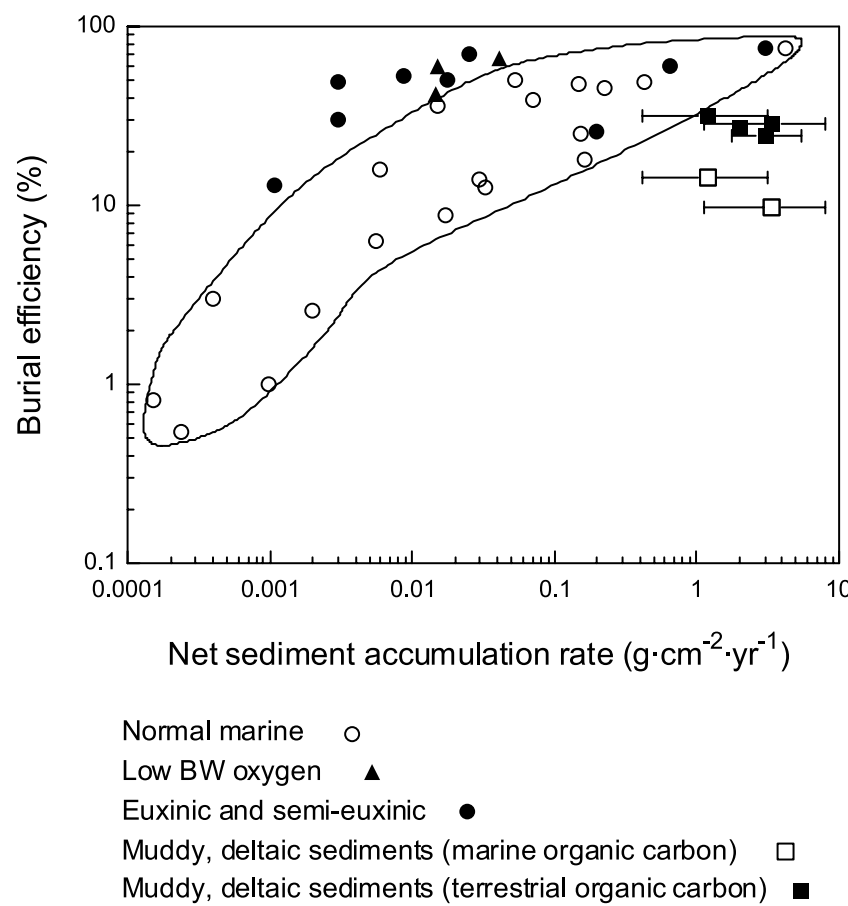

Figure 1. Burial efficiency of sediment organic carbon versus sedimentation rate, for a range of sedimentary environments (modified after Aller [1998] using data cited therein). The envelope shown here defines the commonly observed pattern in normal marine sediments of burial efficiency increasing with increasing sedimentation rate [Canfield, 1994; Henrichs and Reeburgh, 1987]. As discussed in the text, this figure also illustrates two other important points: that deltaic sediments generally show lower burial efficiencies than do normal (i.e., non-deltaic continental margin) marine sediments at the same sedimentation rate; that marine organic carbon is more efficiently remineralized than is terrestrial organic carbon in deltaic sediments. The data shown here from deltaic sediments are for the Amazon and Mississippi River deltas (marine and terrestrial organic matter) and Fly and Chiangiiang River deltas (terrestrial organic matter only).

surface pools of carbon in the oceans, atmosphere, on land, and in marine sediment, and carbon pools that cycle on much longer, geologic timescales, i.e., carbon in sedimentary rock, coal and petroleum deposits [e.g., Berner, 1989; Hedges, 2002].

[6] In recent years, a number of studies have examined different aspects of TOM input, burial and preservation in marine sediments [e.g., Hedges et al., 1997; Keil et al., 1997a; Schlünz and Schneider, 2000; Bianchi et al., 2002; Gordon and Goñi, 2004]. Other studies have also examined more general sediment-organic matter interactions as they relate to overall carbon preservation in sediments [e.g., Hedges and Keil, 1995; Mayer, 1994a, 1994b]. Here I will summarize and synthesize these results, in an effort to gain a more quantitative under- standing of TOM burial in marine sediments than is presented in these works.

\section{The Burial Efficiency of Terrestrial Organic Matter in Marine Sediments}

[7] The approach taken here to examine TOM burial in sediments relies on a number of observations and assumptions. The first of these is that the vast majority of the organic matter in sediments (up to $\sim 90 \%$ ) appears to be intimately associated with mineral particles, largely in the clay- and silt-size fractions [Hedges and Keil, 1995; Keil et al., 1994]. A second key assumption is that mineral surface area is roughly conserved during weathering of continental rocks and transport of terrigenous mineral particles by rivers to the oceans, and ultimately to marine sediments (see discussions by Hedges [2002] and Hedges et al. [1999b]). Together, these considerations suggest that surface areanormalized, organic carbon concentrations should be a very powerful tool for examining carbon exchange and transport between different global reservoirs [Hedges and Keil, 1995; Keil et al., 1997a]. (Note that surface-area normalized TOC concentration is often referred to as the OC:SA ratio or loading.) Finally, stable carbon isotope measurements of sediment TOC are used in the calculations here to differentiate between marine and terrestrial organic matter, on the basis of the general assumption that marine organic matter is more depleted in ${ }^{13} \mathrm{C}$ than is terrestrial organic matter [e.g., Hedges et al., 1997]. Additional details about this approach are discussed in section 3, as are some of the potential problems that may be associated with this approach.

[8] In the discussion here continental margin sediments are divided into deltaic versus non-deltaic sediments (the former representing continental margin sediments associated with large river systems). The primary reason for making this distinction come from results which have indicated distinct differences in the patterns of organic matter preservation and remineralization in these two types of continental margin sediments [e.g., Aller, 1998; McKee et al., 2004]. An example of this is shown in Figure 1, where it is seen that deltaic sediments generally show lower burial efficiencies, at the same sedimentation rate, than do normal marine sediments (i.e., mainly non-deltaic, continental margin sediments).

[9] Looking now at Table 1, we see that the burial efficiency of TOM in all continental margin sediments is quite low, and in fact the value in non-deltaic margin sediments may be lower than that in deltaic sediments. Given the small size of the data set used in these calculations (e.g., see discussions in section 6) some care must be taken in the interpretation of this comparison. However, one possible explanation for this observation involves the validity of the assumption that surface area is conserved during the transport of mineral particles from land to marine sediments. The deposition of autochthonous "marine" particles produced in the water column (i.e., biogenic calcite and opal) has the potential to compromise this assumption, particularly in non-deltaic continental margin sediments (e.g., see related discussions by Gordon and Goñi [2004]). In this case, TOM burial efficiency as 
Table 1. Terrestrial Organic Matter (TOM) Burial Efficiency in Continental Margin Sediments

\begin{tabular}{|c|c|c|c|}
\hline Sediment Type & OC:SA ${ }^{\mathrm{a}}$ & $\mathrm{TOM} / \sum \mathrm{OM}_{\mathrm{bur}}^{\mathrm{b}}$ & TOM Burial Efficiency ${ }^{\mathrm{c}}$ \\
\hline Deltaic sediments & $0.25 \pm 0.08 \mathrm{mg} \mathrm{C} \mathrm{m}^{-2}$ & $67 \pm 24 \%$ & $\begin{array}{l}22 \pm 5 \%^{\mathrm{d}} \\
\sim 25-30 \%^{\mathrm{e}}\end{array}$ \\
\hline $\begin{array}{l}\text { Non-deltaic, continental } \\
\text { margin sediments }\end{array}$ & $0.86 \pm 0.11 \mathrm{mg} \mathrm{C} \mathrm{m}^{-2}$ & $16 \pm 4 \%$ & $17 \pm 4 \%$ \\
\hline
\end{tabular}

${ }^{a}$ The OC:SA ratio for deltaic sediments is from Aller [1998] based on results presented by Keil et al. [1997a] and Mayer [1994b]. More recent results from the Fly River delta [Aller and Blair, 2004] are consistent with these earlier observations. The OC:SA ratio for non-deltaic, continental margin sediments is from Aller [1998] based on results presented by Mayer [1994a, 1994b]. This value is consistent with the commonly cited range of $0.5-1.1 \mathrm{mg}$ $\mathrm{OC} \mathrm{m}^{-2}$ for the OC:SA ratio of typical continental margin sediments [e.g., see Hedges and Keil, 1995]. However, the value reported here is specifically for organic matter being preserved in these sediments (i.e., that which is buried below the zone of early diagenesis).

${ }^{\mathrm{b}}$ This is the TOM buried at depth as a percentage of total sediment organic matter that is buried (from Aller [1998] and references cited therein). These values are based on estimates of the marine versus terrestrial contribution to the total sediment organic matter pool ( $\left.\sum \mathrm{OM}\right)$, that use stable isotope mass balance calculations along with OC:SA measurements.

${ }^{c}$ For each sediment type, burial efficiency is calculated as the value in the first column times the value in the second column divided by the OC:SA of riverine, suspended particles. This latter value was taken to be $0.75 \pm 0.13 \mathrm{mg} \mathrm{C} \mathrm{m}^{-2}$ [Keil et al., 1994, 1997a; Aller, 1998]. Given this approach, burial efficiency is calculated here with respect to riverine input of TOM, rather than TOM deposition in (or rain rate to) the sediments.

${ }^{\mathrm{d}}$ Note that Keil et al. [1997a] estimated a similar value of TOM burial efficiency $(\sim 30 \%)$ for deltaic sediments by largely the same procedure used here.

${ }^{\mathrm{e}}$ Value is based on sediment carbon budgets that use pore water data and direct measurements of remineralization rates [Aller, 1998; Aller et al., 1996]. Given this approach, burial efficiency is calculated here with respect to deposition (rain rate) of terrestrial POC to the sediments, rather than river input. In these calculations the use of stable isotope measurements of pore water $\sum \mathrm{CO}_{2}$ and of the sediment TOC and authigenic carbonates demonstrates that the loss of sediment TOM results from remineralization, as opposed to, for example, desorption or other partitioning mechanisms of mineral-bound TOM into the water column. Note that the individual values used to determine this range are shown in Figure 1.

calculated here would be an underestimate of its true value, due to the addition of "marine" surface area to these sediments. In deltaic sediments however, the input of detrital terrigenous material generally overwhelms the input of biogenic components [e.g., Michalopoulos and Aller, 2004], suggesting that the assumption of conservative mineral surface area is not unreasonable.

[10] The low TOM burial efficiency in deltaic sediments is related, in part, to the fact that deltaic sediments are extensively re-worked physically by shelf currents and tides to sediment depths ranging from $\sim 0.5-2 \mathrm{~m}$. On the Amazon continental shelf, for example, this re-working occurs on daily to seasonal timescales [e.g., DeMaster and Aller, 2001; McKee et al., 2004]. This reworking periodically re-exposes deltaic sediments to oxygen-containing bottom waters, increasing the oxygen "exposure" of the sediments. This oxygen exposure appears to enhance carbon remineralization in sediments [e.g., Aller, 1998, 2004; Hedges et al., 1999a], although many of the details of how this occurs remain to be worked out. Nevertheless, this phenomenon likely plays some role in the resulting low carbon burial efficiencies seen in deltaic sediments.

[11] Physical re-working of deltaic sediments also adds relatively fresh, planktonic organic matter to the sediments. This may then catalyze the oxidation of more refractory components of the sediment organic mater pool (e.g., soil organic matter brought in by rivers) through a process referred to as co-metabolism or co-oxidation [Aller, 1994; Canfield, 1994; Schink, 1988]. By stimulating the overall remineralization of both marine and terrestrial organic matter, co-metabolism may therefore further lead to the low burial efficiencies seen in Figure 1 and Table 1.

[12] In contrast, a different set of factors contribute to the low TOM burial efficiency in non-deltaic continental margin sediments. The first is that some amount of the material deposited in deltaic sediments is subsequently resuspended and redeposited in non-deltaic continental margin sediments (see discussions by Hedges and Keil [1995] and McKee et al. [2004]). As a result, TOM in such sediments will have undergone one remineralization "cycle" in deltaic sediments prior to re-deposition in non-deltaic continental margin sediments.

[13] However more importantly, particles transported from land to the oceans, and eventually to marine sediments, generally appear to exchange (or lose) much of their TOM loading rapidly, and replace it with marine organic matter [Hedges et al., 1997; Keil et al., 1997a; Mayer et al., 1998]. As a result, sediments deposited in non-deltaic continental margin sediments apparently lose much of their TOM loading prior to deposition (also see related discussions in the next section). Therefore, because burial efficiencies have been calculated here with respect to riverine input, these pre-depositional processes lead, in part, to the low TOM burial efficiency estimated here for non-deltaic continental margin sediments. Interestingly though, a comparison of the results in Table 1 suggests that estimates of TOM burial efficiency in deltaic sediments are similar regardless of whether $\mathrm{BE}$ is calculated with respect to riverine input of TOM or TOM deposition in the sediments. Apparently because of their close proximity to river mouths, terrigenous particles are deposited in deltaic sediments before they lose much of their TOM loading.

\section{Composition of Organic Matter Being Buried in Continental Margin Sediments}

[14] Table 1 also indicates that there is a strong difference in the relative TOM content of the organic matter buried at depth in these two different types of continental margin sediments. For deltaic sediments, the large value of TOM/ $\sum \mathrm{OM}_{\text {bur }}$ is likely due to the significant input of TOM to such sediments [e.g., Aller and Blair, 2004], and the fact that while these sediments are efficient at remineralizing terrestrial organic matter, they are even more efficient at 
remineralizing marine organic matter (MOM; see Figure 1 and discussions by Aller et al. [1996, 2004]). Furthermore, because of the dynamics of deltaic sediments, the loss of TOM during sediment diagenesis is apparently not compensated for by the uptake of MOM, as appears to be the case for other riverine particles entering the oceans, including those that are eventually deposited in non-deltaic margin sediments. Thus, along with the high relative concentration of TOM that is buried in these sediments, this also leads to a net decrease in the OC:SA loading of deltaic sediments $\left(\sim 0.3 \mathrm{mg}\right.$ OC $\left.\mathrm{m}^{-2}\right)$ as compared to riverine suspended particles (average of $\sim 0.7 \mathrm{mg}$ OC $\mathrm{m}^{-2}$; see Table 1, footnotes a and c).

[15] In contrast, because of the pre-depositional processes described above, the OC:SA loading of non-deltaic, continental margin sediments $\left(\sim 0.5-1.1 \mathrm{mg} \mathrm{OC} \mathrm{m}^{-2}\right)$ is roughly similar to that of riverine suspended particles, although the composition of the organic matter has been greatly altered by the loss of TOM and its replacement with MOM [Hedges and Keil, 1995; Keil et al., 1997a; Mayer et al., 1998]. As a result, comparatively little TOM is deposited in non-deltaic, continental margin sediments, and coupled with the relatively high burial efficiencies for all organic matter in these sediments (Figure 1) this then leads to a low value of $\mathrm{TOM} / \sum \mathrm{OM}_{\mathrm{bur}}$ in non-deltaic, continental margin sediments.

[16] As was noted above, the differentiation between marine and terrestrial organic matter that is made here is based on stable carbon isotope measurements of the sediment TOC. Before continuing, it is worth examining this assumption, given its potential impact on the results being presented here. Both marine phytoplankton and most land plants (i.e., those that represent the predominant sources of TOM to the oceans) use the same $C_{3}$ carbon fixation pathway (which roughly leads to similar amounts of carbon fractionation during photosynthesis [e.g., Fogel and Cifuentes, 1993]). However, differences in the isotopic composition of the carbon sources used by these plants (mainly seawater bicarbonate for marine phytoplankton, versus atmospheric $\mathrm{CO}_{2}$ for terrestrial plants) leads to the distinct isotopic signatures of these two types of organic matter. As a result, MOM generally has a $\delta^{13} \mathrm{C}$ of -17 to $-22 \%$ while TOM (assuming a $\mathrm{C}_{3}$ plant source) has a $\delta^{13} \mathrm{C}$ of -25 to $28 \%$ (for further details see, e.g., Fogel and Cifuentes [1993] and Hedges et al. [1997]).

[17] Despite these potential differences in $\delta^{13} \mathrm{C}$ of $\mathrm{MOM}$ versus TOM, there are also a number of difficulties in using stable carbon isotopes to differentiate between marine and terrestrial organic matter sources. Perhaps the most relevant one here is that some land plants (e.g., certain temperate grasses) fix carbon using the $\mathrm{C}_{4}$ carbon fixation pathway, which shows much less isotopic discrimination against $\mathrm{CO}_{2}$ [Fogel and Cifuentes, 1993]. Terrestrial organic matter produced by $\mathrm{C}_{4}$ plants is therefore isotopically heavier $\left(-8\right.$ to $-18 \%$ ) than either marine organic matter or $\mathrm{C}_{3^{-}}$ terrestrial plant organic matter. Thus, based solely on $\delta^{13} \mathrm{C}$ measurements of bulk TOC, mixtures of organic carbon from $\mathrm{C}_{3}$ and $\mathrm{C}_{4}$ terrestrial plant sources can, for example, potentially "look" like marine-derived organic matter [e.g., Goñi et al., 1998].
[18] At the same time, because of degradative processes on land, TOM that is transported to the oceans is quite heterogeneous, in terms of its general reactivity, chemical composition, particle-size distribution, and perhaps even its association with mineral particles [e.g., Keil et al., 1998; Onstad et al., 2000; Gordon and Goñi, 2003, 2004]. Coupled with the hydrodynamic sorting of this material that occurs during its offshore sediment transport, such considerations further complicate estimates of TOM input to continental margin sediments [also see Prahl, 1985; Bianchi et al., 2002].

[19] Finally, an additional uncertainty in these calculations comes from recent studies that have demonstrated the input of fossil carbon (recycled kerogen) to continental margin sediments [Blair et al., 2003, 2004; Gordon and Goñi, 2004]. In particular, kerogen associated with marine bedrock is likely to have heavy $\delta^{13} \mathrm{C}$ values, consistent with that of more recent marine organic matter [also see Masiello and Druffel, 2001]. Therefore fossil carbon deposition in marine sediments could potentially lead to an over-estimate of the marine carbon input based on stable carbon isotope measurements.

[20] Given such observations, studies in recent years have begun to use lipid biomarkers, lignin oxidation products, and/or compound-specific stable isotope and radiocarbon measurements in conjunction with bulk tracers such TOC $\delta^{13} \mathrm{C}$, to help better constrain estimates of MOM versus TOM input to continental margin sediments [Goñi et al., 1998; Gough et al., 1993; Keil et al., 1994; Prahl et al., 1994; Gordon and Goñi, 2003, 2004]. Using such approaches, Gordon and Goñi [2003] estimated that TOM accounts for between $\sim 70$ and $80 \%$ of the organic matter deposited on the inner continental shelf $(0-20 \mathrm{~m}$ water depth) of the northern Gulf of Mexico by the Atchafalaya River. Similar studies of the Washington (United States) continental shelf have estimated that $\sim 10-30 \%$ of the organic matter deposited on the outer shelf/continental slope ( 200-2000 m water depth) is of terrestrial origin [Keil et al., 1994; Prahl et al., 1994]. In both cases, these values likely represent minimum estimates of the relative amount of TOM buried at depth in these sediments, depending on the selectivity of MOM versus TOM remineralization in these sediments (also see related discussions by Hedges et al. [1999a]).

[21] Unfortunately, similar multitracer approaches have not yet been used more widely to quantify TOM input or burial in other continental margin sediments (see related discussions by McKee et al. [2004]). Nevertheless, a comparison of the results in Table 1 with the literature results discussed above suggests that the estimates here of TOM/ $\sum \mathrm{OM}_{\text {bur }}$ for these two types of continental margin sediments may not be unreasonable. However, on the basis of the discussions above, it is also clear that more work will be needed to further verify such estimates.

\section{Burial of Terrestrial Organic Matter in Continental Margin Sediments}

[22] When the results in Table 1 are combined with estimates of total carbon burial in marine sediments [Hedges 
Table 2. Burial of Terrestrial Organic Matter (TOM) in Continental Margin Sediments

\begin{tabular}{|c|c|c|c|c|}
\hline \multirow[b]{2}{*}{ Sediment Type } & \multirow[b]{2}{*}{$\mathrm{TOM} / \sum \mathrm{OM}_{\mathrm{bur}}^{\mathrm{a}}$} & \multicolumn{2}{|c|}{ Burial Rate ${ }^{b}$} & \multirow{2}{*}{$\begin{array}{c}\text { TOM Burial } \\
\text { (\% of } \sum \text { OM Burial) }\end{array}$} \\
\hline & & $\sum \mathrm{OM}^{\mathrm{c}}$ & $\mathrm{TOM}^{\mathrm{d}}$ & \\
\hline Deltaic sediments & $67 \pm 24 \%$ & 70 & $47 \pm 17$ & \\
\hline $\begin{array}{l}\text { Non-deltaic, continental } \\
\text { margin sediments }\end{array}$ & $16 \pm 4 \%$ & 68 & $11 \pm 3$ & \\
\hline All continental margin sediments & & 138 & $58 \pm 17$ & $44 \pm 13 \%$ \\
\hline All marine sediments & & 160 & & $36 \pm 11 \%$ \\
\hline
\end{tabular}

and Keil, 1995], the estimated rate of TOM burial in

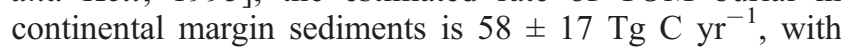
the majority of this burial occurring in deltaic sediments (Table 2). Assuming that TOM burial is insignificant in other sediment regimes, for example, deep-sea sediments [Degens, 1969; Emerson and Hedges, 1988; Hedges, 1992; Gough et al., 1993], this observation implies that approximately one third of the organic matter buried in marine sediments is of terrestrial origin.

[23] For comparison, Schlünz and Schneider [2000] estimated a very similar TOM burial rate in continental margin sediments (43 $\mathrm{Tg} \mathrm{C} \mathrm{yr}^{-1}$ ) using a slightly different approach. In their calculation they assumed a riverine TOM input to the oceans (particulate plus dissolved TOM) of $430 \mathrm{Tg} \mathrm{C} \mathrm{yr}{ }^{-1}$, and a $10 \%$ burial efficiency for all of this material. This $10 \% \mathrm{BE}$ is based on their interpretation of results from the Amazon River/continental margin system, and the assumption that this $\mathrm{BE}$ is representative of all river systems globally. Using this same rate of riverine TOM input, the TOM burial rate calculated in Table 2 similarly implies that the overall burial efficiency of TOM in the oceans is $\sim 9-17 \%$. Although much of the TOM transported by rivers to the oceans is presumed to be relatively refractory (see discussions by Hedges et al. [1997]), both of these calculations suggest that TOM is efficiently remineralized in the oceans.

[24] When compared to the global rate of organic carbon burial in marine sediments $\left(\sim 160 \mathrm{Tg} \mathrm{C} \mathrm{yr}^{-1}\right)$, the results of this calculation suggest that the majority of the organic matter buried in marine sediments $\left(\sim 100 \mathrm{Tg} \mathrm{C} \mathrm{yr}^{-1}\right)$ is of marine origin, and in an absolute sense the burial of MOM is roughly twice that of TOM. However, on the basis of earlier discussions, MOM is (in general) presumed to be more reactive than TOM. This apparently counter-intuitive observation makes more sense, though, when looked at in terms of the overall burial efficiency of MOM with regards to its ultimate oceanic source, primary production in the water column.

[25] Shown in Table 3 are estimates of MOM burial efficiency with respect to surface water primary productivity, for either all marine sediments globally or solely for continental margin sediments. As can be seen here, these estimates of MOM burial efficiency $(0.25 \%$ to $<1.3 \%)$ are less than that for TOM $(\sim 9-17 \%)$, by at least an order of magnitude. Thus from this perspective, it is clear that marine organic matter is much more efficiently remineralized than terrestrial organic matter in the oceans, in spite of the observed trends in the composition of the organic carbon that is buried in marine sediments. Expressed another way, because of the shear magnitude of marine productivity versus riverine input of TOM, more marine organic matter is buried in marine sediments in spite of these differences in MOM versus TOM burial efficiency. Even when burial efficiencies are calculated with respect to carbon deposition (rain rate) to the sediments as in Figure 1, MOM still has a lower burial efficiency than TOM, at least in deltaic sediments. However, in these estimates there is now only about a factor of 2 difference in TOM versus MOM burial efficiency.

\section{A Paleoceanographic Perspective on TOM Burial}

[26] Assuming a river particulate organic matter (POM) discharge of $\sim 170-200 \mathrm{Tg} \mathrm{C} \mathrm{yr}{ }^{-1}$ [Ludwig and Probst, 1996; Schlünz and Schneider, 2000] and a TOM burial

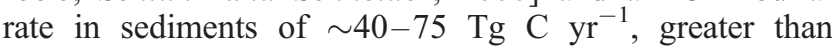
$\sim 100 \mathrm{Tg} \mathrm{C}$ of terrestrial POM is remineralized per year. When compared to results in Table 2 , it can be seen that this lower limit for terrestrial POM remineralization is comparable to the present-day rate of total carbon burial in all marine sediments $\left(\sim 160 \mathrm{Tg} \mathrm{C} \mathrm{yr}^{-1}\right)$.

[27] During low sea level stands (i.e., during glacial times) the absence of significant continental shelves suggests that this amount of terrestrial POM could escape remineralization to $\mathrm{CO}_{2}$, and be directly deposited in deeper water submarine continental fans and lower continental slope sediments. Consistent with this suggestion are the observations of elevated amounts of TOM in Glacial-age sediments in the Amazon Fan [Goñi, 1997; Keil et al., 1997b] and in the Mississippi Cone in the Gulf of Mexico [Newman et al., 1973]. This therefore suggests that the fate of TOM in marine sediments has the potential to impact the global carbon cycle on glacialinterglacial timescales (see related discussions by Keil et al. [1997a]).

[28] Past studies have also suggested that a decrease in terrestrial organic carbon storage on land during Glacial times (often-times thought of as a "collapse" of the terrestrial biosphere) ultimately represented a source of $\mathrm{CO}_{2}$ to 
Table 3. Estimates of the Marine Organic Carbon Burial Efficiency in Marine Sediments With Respect to Surface Water Primary Productivity

\begin{tabular}{|c|c|c|}
\hline Oceanic Regime & Primary Production, ${ }^{\mathrm{a}} \mathrm{Gt} \mathrm{C} \mathrm{yr}^{-1}$ & Burial Efficiency \\
\hline $\begin{array}{l}\text { Global ocean } \\
\text { Continental margin }\end{array}$ & $\begin{array}{l}40 \\
7.8^{\mathrm{c}} \\
\end{array}$ & $\begin{array}{l}0.25 \%{ }^{\mathrm{b}} \\
<1.3 \%{ }^{\mathrm{d}} \\
\end{array}$ \\
\hline $\begin{array}{l}{ }^{\mathrm{a}} \text { All productivity } \\
{ }^{\mathrm{b}} \text { Value is based or } \\
\text { global ocean of } 100 \\
{ }^{\mathrm{c}} \text { Productivity esti } \\
\text { oceanic region in } \\
\text { region is clearly sme } \\
\text { limit for continental } \\
\text { efficiency is an upp } \\
{ }^{\mathrm{d}} \text { Value is based c } \\
86 \mathrm{Tg} \mathrm{C} \mathrm{yr}{ }^{-1} \text { in } \\
100 \mathrm{Tg} \mathrm{C} \mathrm{yr}{ }^{-1} \text { min } \\
\text { sediments }(=10 \text { T } \\
\left(=5 \mathrm{Tg} \mathrm{C} \mathrm{yr}{ }^{-1} \text { ) ar }\right. \\
\text { burial estimates for } \\
\text { and Keil }[1995] \text {. }\end{array}$ & $\begin{array}{l}\text { stimates are from Liu et al. } \\
\text { an assumed marine organic carb } \\
\text { Tg C } \mathrm{yr}^{-1}\left(=0.1 \mathrm{Gt} \mathrm{C} \mathrm{yr}^{-1} \text {; see }\right. \\
\text { nate is for the coastal ocean, } \\
\text { ich waters depths are less than } \\
\text { ler than the entire continental ma } \\
\text { nargin productivity. As a result th } \\
\text { limit. } \\
\text { an assumed marine organic ca } \\
\text { ontinental margin sediments. Th } \\
\text { s that accumulating in high-proc } \\
\left.\mathrm{C} \mathrm{yr}^{-1}\right) \text {, low-productivity, } \\
\text { anoxic basins (=1 Tg } \mathrm{C} \mathrm{yr} \\
\text { non-continental margin sediment }\end{array}$ & $\begin{array}{l}\text { burial rate in the } \\
\text { e text for details). } \\
\text { fined here as the } \\
200 \mathrm{~m} \text {. Since this } \\
\text { gin, this is a lower } \\
\text { estimate of burial } \\
\text { bon burial rate of } \\
\text { s is calculated as } \\
\text { ictivity, biogenous } \\
\text { elagic sediments } \\
\text { Organic carbon } \\
\text { are from Hedges }\end{array}$ \\
\hline
\end{tabular}

the Glacial atmosphere (see Sigman and Boyle [2000] for a summary). At the same time though, the processes described above suggest a way in which the enhanced burial of TOM in marine sediments during the low sea level stands of glacial times could represent a sink for atmospheric $\mathrm{CO}_{2}$. However, more work will be needed to further examine the possible importance of TOM burial in impacting glacialinterglacial changes in atmospheric $\mathrm{CO}_{2}$.

\section{Closing Thoughts}

[29] When the problem of TOM reactivity in the oceans and burial of marine sediments is re-examined in the context of results presented here, the geochemical conundrum that Hedges et al. [1997] refer to may not be as severe as once thought. Nevertheless, as the discussion here also indicates, a number of key problems still exist that will require further study in order to verify the calculations presented here, and the assumptions therein, and therefore better constrain the rate of TOM burial in marine sediments.

[30] In particular, given the key role that deltaic sediments appear to play as sites of TOM burial, there is a strong need to increase our quantitative understanding of biogeochemical processes occurring in deltaic sediments. For example, the calculations presented here are largely based on results from only four deltaic systems (e.g., see Figure 1), which may or may not be representative of such river-dominated margin settings worldwide. Furthermore, sampling of these systems must also take into account their temporal and spatial variability, to adequately quantify diagenetic processes occurring in these sediments (e.g., see discussions by McKee et al. [2004] for further details). At the same time, the discussions above indicate that more work is needed to better understand the heterogeneity of TOM, the transport processes affecting its deposition in deltaic sediments (and continental margin sediments in general), and the possible input of fossil carbon to continental margin sediments. In part, the continued use and development of biomarkers for different terrestrial organic matter sources [e.g., Hopmans et al., 2004] will hopefully aid in addressing problems such as these.

\section{Conclusions}

[31] The calculations presented here demonstrate that the remineralization of "refractory" terrestrial organic matter in the oceans is indeed much less efficient than that of (presumably) more "reactive" marine organic matter. However, because of the shear magnitude of marine productivity (photosynthesis) versus riverine input of TOM, more MOM than TOM is buried in marine sediments. Nevertheless, TOM still appears to represent approximately one third of the organic matter buried in all marine sediments, with the majority of this burial occurring deltaic, continental margin sediments. While recent studies have begun to provide an explanation for how this may occur, many of the mechanistic details of how MOM and TOM preservation occurs in marine sediments still remain to be worked out.

[32] Acknowledgments. The work of many people, but particularly Larry Mayer, Bob Aller, and the late John Hedges, provided the material that I have summarized and synthesized here. I would like to thank them for these important contributions to the field, and for the many discussions I have had with them over the years about marine geochemistry and sediment carbon preservation. I would also like to thank the anonymous reviewers of this manuscript, who provided me with useful comments that greatly improved the quality of this work.

\section{References}

Aller, R. C. (1994), Bioturbation and remineralization of sedimentary organic matter: Effects of redox oscillation, Chem. Geol., 114, 331-345.

Aller, R. C. (1998), Mobile deltaic and continental shelf muds as suboxic, fluidized bed reactors, Mar. Chem., 61, 143-155.

Aller, R. C. (2004), Conceptual models of early diagenetic processes: The muddy seafloor as an unsteady, batch reactor, J. Mar. Res., 62, 815-835.

Aller, R. C., and N. E. Blair (2004), Early diagenetic remineralization of sedimentary organic $\mathrm{C}$ in the Gulf of Papua deltaic complex (Papua New Guinea): Net loss of terrestrial $\mathrm{C}$ and diagenetic fractionation of $\mathrm{C}$ isotopes, Geochim. Cosmochim. Acta, 68, 1815-1825.

Aller, R. C., N. C. Blair, Q. Xia, and P. D. Rude (1996), Remineralization rates, recycling and storage of carbon in Amazon shelf sediments, Cont. Shelf Res., 16, 753-786.

Aller, R. C., A. Hannides, C. Heilbrun, and C. Panzeca (2004), Coupling of early diagenetic processes and sedimentary dynamics in tropical shelf environments: The Gulf of Papua deltaic complex, Cont. Shelf. Res., $24,2455-2486$.

Berner, R. A. (1989), Biogeochemical cycles of carbon and sulfur and their effect on atmospheric oxygen over Phanerozoic time, Paleogeogr. Paleoclimatol. Paleoecol., 75, 97-122.

Berner, E. K., and R. A. Berner (1996), Global Environment: Water, Air, and Geochemical Cycles, Prentice-Hall, Upper Saddle River, N. J.

Bianchi, T. S., S. Mitra, and B. A. McKee (2002), Sources of terrestriallyderived organic carbon in lower Mississippi River and Louisiana shelf sediments: Implications for differential sedimentation and transport at the coastal margin, Mar. Chem., 77, 211-223.

Blair, N. E., E. L. Leithold, S. T. Ford, K. A. Peeler, J. C. Holmes, and D. W. Perkey (2003), The persistence of memory: The fate of ancient sedimentary organic carbon in a modern sedimentary system, Geochim. Cosmochim. Acta, 67, 63-73.

Blair, N. E., E. L. Leithold, and R. C. Aller (2004), From bedrock to burial: the evolution of particulate organic carbon across coupled watershedcontinental margin systems, Mar. Chem., 92, 141-156.

Burdige, D. J. (1991), The kinetics of organic matter mineralization in anoxic marine sediments, J. Mar. Res., 49, 727-761.

Canfield, D. E. (1994), Factors influencing organic matter preservation in marine sediments, Chem. Geol., 114, 315-329.

Cowie, G. L., J. I. Hedges, and S. E. Calvert (1992), Sources and reactivity of amino acids, neutral sugars, and lignin in an intermittently anoxic marine environment, Geochim. Cosmochim. Acta, 56, 1963-1978. 
Degens, E. T. (1969), Biogeochemistry of stable carbon isotopes, in Organic Geochemistry, edited by G. Eglinton and M. T. J. Murphy, pp. 304-329, Springer, New York.

DeMaster, D. J., and R. C. Aller (2001), Biogeochemical processes on the Amazon shelf: Changes in dissolved and particulate fluxes during river/ ocean mixing, in The Biogeochemistry of the Amazon Basin, edited by M. E. McClain, R. L. Victoria, and J. E. Richey, pp. 328-357, Oxford Univ. Press, New York.

Emerson, S., and J. I. Hedges (1988), Processes controlling the organic carbon content of open ocean sediments, Paleoceanography, 3, 621634

Fogel, M. L., and L. A. Cifuentes (1993), Isotope fractionation during primary production, in Organic Geochemistry, edited by S. A. Macko and M. H. Engel, pp. 73-98, Springer, New York.

Goñi, M. A. (1997), Records of terrestrial organic matter composition in Amazon Fan sediments, in Proceedings of the Ocean Drilling Program, Scientific Results, vol. 155, edited by R. D. Flood, D. J. W. Piper, and L. C. Peterson, pp. 519-530, Ocean Drill. Program, College Station, Tex.

Goñi, M. A., K. C. Ruttenberg, and T. I. Eglinton (1998), A reassessment of the sources and importance of land-derived organic matter in surface sediments from the Gulf of Mexico, Geochim. Cosmochim. Acta, 62, $3055-3075$

Gordon, E. S., and M. A. Goñi (2003), Sources and distribution of terrigenous organic matter delivered by the Atchafalaya River to sediments in the northern Gulf of Mexico, Geochim. Cosmochim. Acta, 67, 23592375.

Gordon, E. S., and M. A. Goñi (2004), Controls on the distribution of and accumulation of terrigenous organic matter in sediments from the Mississippi and Atchafalaya river margins, Mar. Chem., 92, 331-352.

Gough, M. A., R. Fauzi, C. Mantoura, and M. Preston (1993), Terrestrial plant biopolymers in marine sediments, Geochim. Cosmochim. Acta, 57 945-964.

Hedges, J. I. (1992), Global biogeochemical cycles: Progress and problems, Mar. Chem., 39, 67-93.

Hedges, J. I. (2002), Sedimentary organic matter preservation and atmospheric $\mathrm{O}_{2}$ regulation, in Chemistry of Marine Water and Sediments, edited by A. Gianguzza, E. Pelizzetti, and S. Sammartano, pp. 105123, Springer, New York.

Hedges, J. I., and R. G. Keil (1995), Sedimentary organic matter preservation: an assessment and speculative synthesis, Mar. Chem., 49, 81-115.

Hedges, J. I., R. G. Keil, and R. Benner (1997), What happens to terrestrial organic matter in the ocean?, Org. Geochem., 27, 195-212.

Hedges, J. I., F. S. Hu, A. H. Devol, H. E. Hartnett, E. Tsamakis, and R. G. Keil (1999a), Sedimentary organic matter preservation: A test for selective degradation under oxic conditions, Am. J. Sci., 299, 529-555.

Hedges, J. I., R. G. Keil, C. Lee, and S. G. Wakeham (1999b), Invited lecture: Atmospheric $\mathrm{O}_{2}$ control by a 'mineral conveyor belt' linking the continents and ocean, in Geochemistry of the Earth's Surface: Proceedings of the 5th International Symposium on the Geochemistry of the Earth's Surface, edited by H. Armannsson, pp. 241-244, A. A. Balkema, Brookfield, Vt.

Henrichs, S. M., and W. S. Reeburgh (1987), Anaerobic mineralization of marine sediment organic matter: rates and the role of anaerobic processes in the oceanic carbon economy, Geomicrobiol. J., 5, 191-237.

Hopmans, E. C., J. W. H. Weijers, E. Schefuß, L. Herfort, J. S. Sinninghe Damsté, and S. Schouten (2004), A novel proxy for terrestrial organic matter in sediments based on branched and isoprenoid tetraether lipids, Earth Planet. Sci. Lett., 224, 107-116.

Keil, R. G., E. Tsamakis, C. B. Fuh, C. Giddings, and J. I. Hedges (1994), Mineralogical and textural controls on organic composition of coastal marine sediments: hydrodynamic separation using SPLITT fractionation, Geochim. Cosmochim. Acta, 58, 879-893.

Keil, R. G., L. M. Mayer, P. D. Quay, J. E. Richey, and J. I. Hedges (1997a), Loss of organic matter from riverine particles in deltas, Geochim. Cosmochim. Acta, 61, 1507-1511.
Keil, R. G., E. C. Tsamakis, N. Wolf, J. I. Hedges, and M. A. Goñi (1997b), Relationships between organic carbon preservation and mineral surface area in Amazon Fan sediments (Holes 932A and 942A), in Proceedings of the Ocean Drilling Program, Scientific Results, vol. 155, edited by R. D. Flood, D. J. W. Piper, and L. C. Peterson, pp. 531-538, Ocean Drill. Program, College Station, Tex.

Keil, R. G., E. Tsamakis, J. C. Giddings, and J. I. Hedges (1998), Biochemical distributions (amino acids, neutral sugars, and lignin phenols) among size-classes of modern sediments from the Washington coast, Geochim. Cosmochim. Acta, 62, 1347-1364.

Liu, K.-K., K. Iseki, and S.-Y. Chao (2000), Continental margin carbon fluxes, in The Changing Ocean Carbon Cycle, edited by R. B. Hanson, H. W. Ducklow, and J. G. Field, pp. 187-240, Cambridge Univ. Press, New York.

Ludwig, W., and J.-L. Probst (1996), Predicting the input of organic carbon by continental erosion, Global Biogeochem. Cycles, 10, 23-41.

Masiello, C. A., and E. R. M. Druffel (2001), Carbon isotope geochemistry of the Santa Clara River, Global Biogeochem. Cycles, 15, 407-416.

Mayer, L. M. (1994a), Relationships between mineral surfaces and organic carbon concentrations in soils and sediments, Chem. Geol., 114, $347-$ 363.

Mayer, L. M. (1994b), Surface area control of organic carbon accumulation in continental margin sediments, Geochim. Cosmochim. Acta, 58, 1271 1284 .

Mayer, L. M., R. G. Keil, S. A. Macko, S. B. Joye, K. C. Ruttenberg, and R. C. Aller (1998), Importance of suspended particulates in riverine delivery of bioavailable nitrogen to coastal zones, Global Biogeochem Cycles, 12, 573-579.

McKee, B. A., R. C. Aller, M. A. Allison, T. S. Bianchi, and G. C. Kineke (2004), Transport and transformation of dissolved and particulate materials on continental margins influenced by major rivers: Benthic boundary layer and seabed processes, Cont. Shelf. Res., 24, 899-926.

Michalopoulos, P., and R. C. Aller (2004), Early diagenesis of biogenic silica in the Amazon delta: Alteration, authigenic clay formation, and storage, Geochim. Cosmochim. Acta, 68, 1061-1085

Newman, J. W., P. L. Parker, and E. W. Behrens (1973), Organic carbon ratios in Quaternary cores from the Gulf of Mexico, Geochim. Cosmochim. Acta, 37, 225-238

Onstad, G. D., D. E. Canfield, P. D. Quay, and J. I. Hedges (2000), Sources of particulate organic matter in rivers from the continental USA: Lignin phenol and stable carbon isotope compositions, Geochim. Cosmochim. Acta, 64, 3539-3546.

Prahl, F. G. (1985), Chemical evidence of differential particle dispersal in the southern Washington coastal environment, Geochim. Cosmochim. Acta, 49, 2533-2539.

Prahl, F. G., J. R. Ertel, M. A. Goni, M. A. Sparrow, and B. Eversmeyer (1994), Terrestrial organic carbon contributions to sediments on the Washington margin, Geochim. Cosmochim. Acta, 58, 3035-3048.

Prahl, F. G., G. H. de Lange, S. Scholten, and G. L. Cowie (1997), A case of post-depositional aerobic degradation of terrestrial organic matter in turbidite deposits from the Madeira Abyssal Plain, Org. Geochem., 27, $141-152$.

Schink, B. (1988), Principles and limits of anaerobic degradation: environmental and technological aspects, in Biology of Anaerobic Microorganisms, edited by A. J. B. Zehnder, John Wiley, Hoboken, N. J.

Schlünz, B., and R. R. Schneider (2000), Transport of terrestrial organic carbon to the oceans by rivers: Re-estimating flux- and burial rates, Int J. Earth Sci., 88, 599-606.

Sigman, D. M., and E. A. Boyle (2000), Glacial/interglacial variations in atmospheric carbon dioxide, Nature, 407, 859-869.

D. J. Burdige, Department of Ocean, Earth and Atmospheric Sciences, Old Dominion University, Norfolk, VA 23529, USA. (dburdige@odu.edu) 